\title{
PEMETAAN SISTEM STRUKTUR KONSTRUKSI RUMAH TRADISIONAL ACEH DALAM MERESPON GEMPA
}

\author{
Erna Meutia \\ Jurusan Arsitektur Fakultas Teknik Universitas Syiah Kuala \\ Jln. Teuku Nyak Arief Darussalam, Banda Aceh \\ *Email: ernameutia@yahoo.co.id
}

\begin{abstract}
ABSTRAK
Rumah-rumah tradisional yang tersebar di seluruh Indonesia merupakan kekayaan budaya yang terbentuk berdasarkan pengetahuan yang diturunkan secara turun temurun. Pengetahuan bangunan yang merespon alam telah menghasilkan bangunan dengan teknologi sederhana. Teknik membangun Rumah tradisional hanya berdasarkan pengetahuan dan intuisi yang di dapat dari kondisi alam setempat serta pengalaman yang diturunkan secara turun temurun. Sebagaimana kita ketahui rumah-rumah tradisional tersebut tidak pernah direncanakan untuk suatu bangunan yang tahan gempa, Meskipun demikian rumah-rumah tradisional tersebut tetap kokoh berdiri walaupun sering terjadi gempa. Hal ini telah dibuktikan oleh rumah tradisional Aceh yang berada di wilayah gempa kuat. Aceh termasuk dalam kawasan Indonesia, terletak di ujung Utara pulau Sumatera, berada pada wilayah gempa 6 yang merupakan wilayah gempa terkuat. Rumah Tradisional Aceh adalah rumah kayu yang berbentuk panggung, didirikan di atas sejumlah tiang-tiang bulat yang diletakkan di atas pondasi batu. Setiap bagian-bagian pembentuk Rumah Tradisional Aceh di hubungkan dengan sambungan menerus yang diperkuat dengan pasak atau 'bajo' dan ikatan tali ijuk. Masing-masing bagian ini saling mendukung untuk mempertahankan konstruksinya terhadap goncangan gempa yang terjadi. Oleh karena itu Rumah tradisional Aceh memiliki keunggulan secara struktural dalam merespon gempa.
\end{abstract}

Kata Kunci: Rumoh Aceh, Gempa, Bagian-bagian Pembentuk Struktur, Sistem Sambungan.

\section{PENDAHULUAN}

Pada dasarnya gempa merupakan suatu gejala alam yang tidak dapat diprediksi besar dan waktu terjadinya. Gempa disebabkan oleh getaran-getaran yang timbul pada permukaan bumi yang diikuti oleh suatu pelepasan energi secara tiba-tiba. Pelepasan energi ini dapat menyebabkan terjadinya patahan-patahan dan perubahan bentuk pada struktur lapisan kulit bumi. Pelepasan energi ini disebabkan oleh pergerakan lempeng tektonik. Ada tiga macam pergerakan lempeng yang terjadi pada permukaan bumi yaitu pergerakan yang saling mendekat, saling menjauh, saling berpapasan (Soehaimi, 1996).

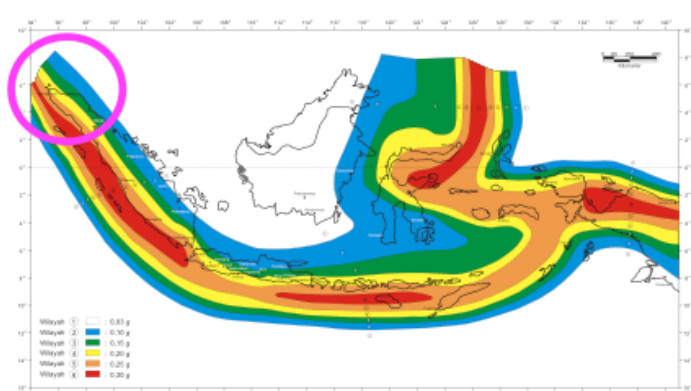

Gambar 1. Pembagian Wilayah Gempa Indonesia

Indonesia merupakan negara yang terletak pada pertemuan empat lempeng tektonik yaitu lempeng Indo-Australia, lempeng Filipina, lempeng Eurasia, dan lempeng Pasifik (Kusuma, 1993). Akibat pertemuan keempat lempeng tersebut menyebabkan beberapa daerah di Indonesia membentuk jalur gunung berapi dan sering mengalami gempa. Hampir seluruh wilayah di Indonesia Rawan Bencana, hanya sepanjang timur Sumatera, Kalimantan dan 
Papua Selatan yang relatif aman terhadap bahaya gempa.

Sesuai dengan aktivitas gempa yang ada, Indonesia dibagi atas 6 wilayah gempa, Wilayah 1 sampai dengan wilayah 6 . Wilayah 1 adalah wilayah gempa terlemah atau wilayah yang tidak pernah terjadi gempa sedangakan wilayah 6 adalah wilayah gempa terkuat. Aceh termasuk ke dalam wilayah gempa kuat, dimana telah terjadi beberapa gempa kuat diantaranya gempa dengan magnitude 6.8 SR (4 April 1983), magnitude 9.2 SR (26 Desember 2004), magnitude 7,3 SR (21 Maret 2008) dan magnitude 8.6 SR (11 April 2012). Rentetan peristiwa ini berdampak terhadap kerusakan besar pada bangunan. Namun Rumah Tradisional Aceh masih tetap kokoh berdiri. Hal ini telah membuktikan bahwa rumah Aceh merupakan suatu banguna yang tahan gempa. Oleh karena itu, sudah seharusnya kita mengkaji secara ilmiah keungulan-keungulan yang telah diperlihatkan oleh arsitektur rumah tradisional Aceh ditinjau dari aspek gempa.

Rumah Tradisional Aceh merupakan salah satu kekayaan budaya Indonesia yang dibangun berdasarkan pengetahuan dan intuisi yang di dapat dari kondisi alam setempat serta pengalaman yang diturunkan secara turun temurun. Sebagaimana kita ketahui Rumah Tradisional Aceh tidak pernah direncanakan sebagai suatu bangunan yang tahan gempa, melainkan bangunan yang dihasilkan dari tangan-tangan trampil seorang tukang atau 'utoeh' untuk memberikan naungan yang aman dan nyaman bagi penghuninya. Pengetahuan membangun yang diperoleh melalui tranfer knowledge antar generasi ke generasi berikutnya.

Pengetahuan yang diperoleh bukan hanya menyangkut aspek tektonika saja melainkan juga pengetahuan filosofi dan makna yang terkandung pada setiap aspek dan bagianbagian pada bangunan. Pemahaman tentang merencanakan kekokohan bangunan terhadap gempa hanya berdasarkan pengetahuan yang diturun secara turun temurun yang tidak pernah dianalisi secara ilmiah. Secara umum kajian ini bertujuan untuk memetakan bagian-bagian dari pembentuk struktur konstruksi Rumah Tradisional Aceh memiliki kemampuan dalam merespon gempa yang terjadi.

Rumah Aceh terbentuk secara tektonik dari kontruksi rangka yang membentuk ruang. Bagian bawah rumah(kolong) dan badan rumah membentuk sosok kotak segi empat dan bagian atas rumah (atap) mengamabarkan unsur-unsur segitiga. Elemen-elemn pembentuk rumah secara umum dibagi jadi tiga bagian yakni kolong sebgai kaki bangunan, badang brumah dan bagian kepala (atap). Proporsi kaki (kolong dan atap terlihat sangat dominan dibanding badan rumah. Posisi rumah (sisi terpendek) berorientasi ke arah barat (kiblat), dipengaruhi oleh kpercayaan agama dan arah datangnya angin barat.

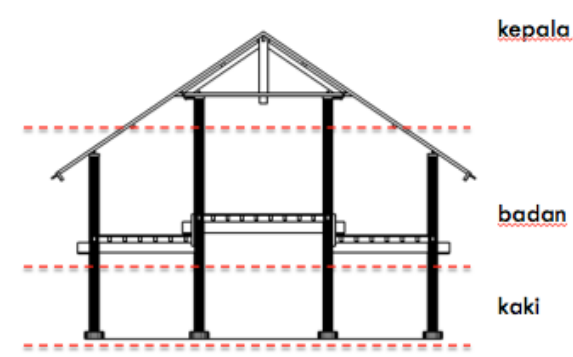

Gambar 2. Pembagian Konstruksi Rangka Rumah Tradisional Aceh

Rumah Aceh digunakan sebagai bangunan tempat tinggal, yang terdiri atas tiga ruang, yaitu seuramoe keue, seuramoe likot dan tungai. Letak ketiga ruang itu tidak sama rata, dimana ruang tengah lebih tinggi dari pada ruang depan dan belakang. Keseluruhan ruangan berbentuk empat persegi, dimana ruang tengah yang disebut tungai letaknya lebih tinggi setengah meter dari ruang depan yang disebut seuramoe keue dan ruang belakang disebut seuramoe likot. Pada ruangan tengan terdapat dua buah kamar yang terletak di ujung sebelah kanan (anjong) dan diujung sebelah kiri (rumoh inong).

Bahan bangunan yang dipergunakan untuk mendirikan rumoh Aceh sangat bervariasi. Bahan-bahan tersebut terpilih dari jenis-jenis kayu tertentu, dimana untuk kerangka dasar dipilih kayu yang kuat dan lurus. Kayu yang dugunakan untuk tiang dipilih dari jenis kayu yang keras dan berwarna gelap kecoklatan. Sedangkan untuk bagian yang bukan merupakan kerangka dasar digunakan jenis kayu yang lebih ringan dari jenis kayu yang digunakan untuk tameh dan toi. Bahan-bahan tersebut kemudian dijadikan berbagai macam komponenkomponen rangka rumah tradisional Aceh, seperti terlihat pada Gambar 3 . 


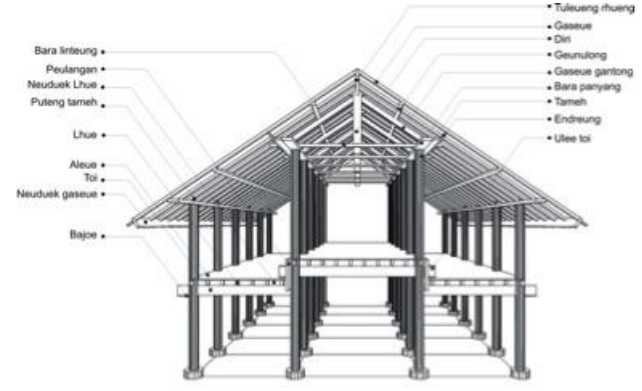

Gambar 3. Elemen Pembentuk Rumah Tradisional Aceh

Adapun elemen pembentuk rangka utama rumah Aceh terdiri:

1. Pondasi atau landasan tiang yang disebut gaki tameh menggunakan batu sungai, diletakkan diatas tanah dasar yang telah ditinggikan sekitar $30 \mathrm{~cm}$ atau disebut teunamba'.

2. Tiang atau tameh sebagai salah satu kerangka utama yang menahan atap, menggunakan kayu bulat.

3. Balok yang menghubungkan tiang-tiang dalam arah memanjang disebut ro' dan melintang disebut toi.

4. Balok untuk menahan lantai disebut lhue.

5. Sebagai penahan atap menggunakan balok kayun yang disbut bara panyang dan bara linteung, indreng, diri, tuleung reung, dan gaseue.

6. Sedangkan untuk dinding atau binteh dan lantai atau aleu menggunakan papan.

Setelah komponen rangka rumah Aceh telah tersedia, maka tahap selanjutnya adalah merangkai masing-masing komponen pembentuk rangka dengan sistem sambungan knockdown yang dapat dibongkar pasang kembali.

Seperti yang diketahui gaya gempa dapat terjadi dalam tiga arah yaitu dalam arah horizontal (X dan $\mathrm{Y}$ ) dan dalam arah vertikal (Z). Selama terjadinya gempa, tanah dapat bergerak kekanan dan kekiri dalam arah $\mathrm{X}, \mathrm{Y}$ maupun keatas dan kebawah dalam arah $\mathrm{Z}$. Gaya gempa horizontal baik dalam arah $X$ maupun $\mathrm{Y}$ tetap menjadi perhatian, dimana suatu struktur telah direncanakan dapat menahan beban berat sendiri bangunan, secara keseluruhan mungkin tidak dapat untuk menahan dengan baik pengaruh dari gaya gempa horizontal. Oleh karena itu perlu untuk memastikan bahwa struktur dapat menahan pengaruh beban gempa dalam arah horizontal.
Besarnya gaya gempa disebabkan oleh gerakan adalah sebanding dengan beban mati dari struktur. Besarnya beban mati mencerminkan karakteristik terhadap respon dinamik struktur bangunan. Pengaruh lain dari respon struktur adalah periode dasar getaran dan penyerapan energi gempa. Pada dasarnya periode getaran ditentukan oleh massa, kekakuan dan besarnya struktur. Sedangkan energi efisiensi ditentukan oleh elastisitas stuktur dan faktor-faktor lainnya seperti kelenturan tumpuan, kekakuan dan sambungan.

Sebuah bangunan dapat diibaratkan seperti susunan atap (kepala) yang disangga oleh dinding (badan) dan bertumpu di atas pondasi (kaki). Apabila gempa terjadi, maka bumi akan bergoyang dan bangunan juga akan ikut bergoyang pula, namun masing-masing bagian dari bangunan akan bergoyang sesuai kekuatannya. Masing-masing bagian dari bangunan seperti kepala, badan dan kaki memiliki berat, kekakuan yang berbeda-beda. Secara keseluruhan gaya inersia bangunan akan sama dengan percepatan dikalikan massa bangunan tersebut, akibatnya masing-masing komponen bangunan (atap, dinding, dan pondasi) akan mempertahankan kekokohannya, seperti Gambar 4.

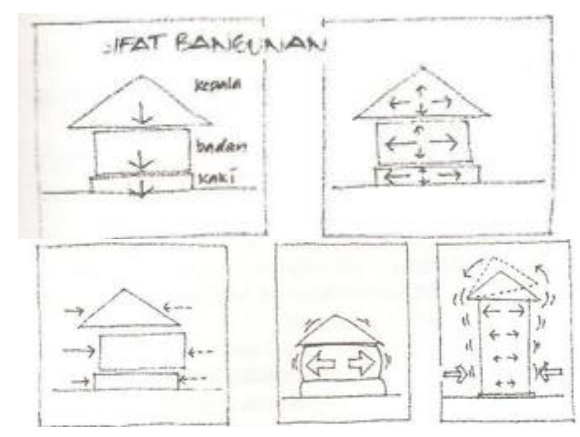

Gambar 4. Sifat Bangunan terhadap Gempa

\section{METODE PENELITIAN}

Penelitian ini mengamati perilaku elemen-elemen pembentuk sistem struktur rumah tradisional Aceh dalam merespon gempa secara langsung. Metode penelitian yang digunakan metode Experimental melalui pengamatan maket model Rumah Tradisional Aceh. Berdasarkan hasil penelitian ini diharapkan akan terpetakan sistem struktur konstruksi Rumah Tradisional Aceh dalam merespon gempa. 
Pemodelan rumah Aceh dalam bentuk maket yang terskala dianggap dapat mewakili bentuk rumah Aceh yang sebenarnya, sehingga perilaku elemen-elemen pembentuk rumah Aceh dalam merespon gempa terekam dengan baik. Perlakuan gempa terhadap model rumah Aceh dilakukan dengan menggunakan peralatan meja getar atau shacking table. Penelitian ini menggunakan model rumah Aceh dalam bentuk maket yang terskala dengan perbandingan 1:10. Adapun proses pembuatan maket rumah Aceh dilakukan dengan survey awal terhadap bentuk prototype rumah Aceh yang sesungguhnya. Maket model rumah Aceh berdasarkan prototype rumah Aceh Profesor Ibrahim Hassan di Jalan Sudirman No. 1 Banda Aceh (Gambar 5).

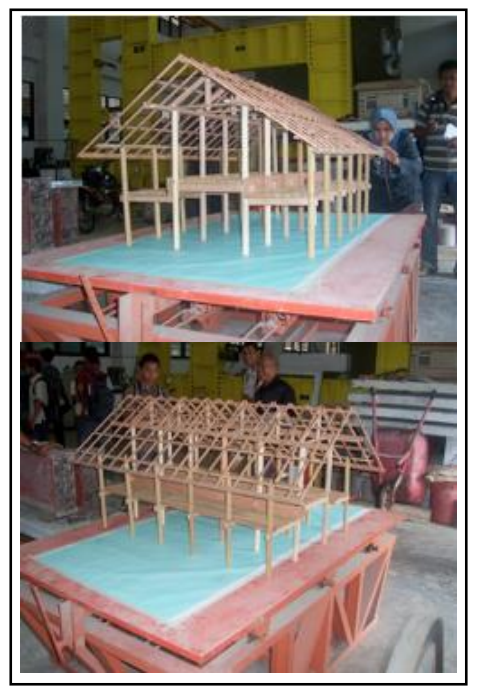

Gambar 5. Maket Model Rumah Tradisional Aceh

Pengamatan dilakukan terhadap perilaku dari elemen-elemen struktural rumah Aceh dalam menahan beban gempa horizontal. Pengamatan dilakukan terhadap maket rumah Aceh dalam arah memanjang dan dalam arah melintang dan secara bertahap seperti pada Tabel 1. Besarnya beban gempa didasarkan pada putaran tuas yang menyebabkan regangan pada pegas, kemudian tuas dilepaskan. Besarnya beban gempa dilakukan secara bertahap. Masing-masing regangan pegas yang akan dilakukan dengan putaran tuas, yaitu 6,8 , dan 10 putaran.

Analisa data dilakukan dalam bentuk tabulasi pengamatan terhadap masing-masing elemen struktur pembentuk rumah Aceh. Hasil analisa akan menunjukkan perilaku dan karakteristik masing-masing pembentuk sistem struktur rumah Aceh.
Pembahasan dari hasil penelitian ini juga akan memaparkan hasil kajian pendahuluan berupa mengamati pengaruh gempa terhadap struktur Rumah Tradisional Aceh. Penelitian ini menggunakan simulasi komputer dengan bantuan perangkat lunak SAP 2000. Simulasi komputer yang dilakukan dengan menggunakan model struktur elemen frame dalam bentuk 3 dimensi.

Metode analisis yang digumakan dalam penelitian ini adalah metode kuantitatif melalui pendekatan deskriptif. Tinjauan analisis yang dilakukan dari hasil pengamatan langsung menggunakan maket model Rumah Tradisional Aceh dengan shacking table dan hasil perhitungan simulasi komputer adalah melihat bagaimana respon gempa terhadap elemenelemen pembentuk rumah tradisional sehingga dapat terpetakan sistem struktur rumah tradisional Aceh mempertahankan diri terhadap gempa.

\section{HASIL DAN PEMBAHASAN}

Gaya gempa dapat terjadi dalam tiga arah yaitu dalam arah horizontal (X dan $\mathrm{Y}$ ) dan dalam arah vertikal $(Z)$. Selama terjadinya gempa, tanah dapat bergerak kekanan dan kekiri dalam arah X, Y maupun keatas dan kebawah dalam arah Z. Gaya gempa horizontal baik dalam arah $\mathrm{X}$ maupun $\mathrm{Y}$ tetap menjadi perhatian, dimana suatu struktur telah direncanakan dapat menahan beban berat sendiri bangunan, secara keseluruhan mungkin tidak dapat untuk menahan dengan baik pengaruh dari gaya gempa horizontal. Oleh karena itu perlu untuk memastikan bahwa struktur dapat menahan pengaruh beban gempa dalam arah horizontal.

Sistem struktur pada konstruksi Rumah Tradisional Aceh merupakan sistem Struktur Rangka. Sistem struktur rangka merupakan sistem struktur yang menahan beban bangunan adalah balok dan kolom. Joint pada hubungan balok dan kolom dapat berupa hubungan bebas maupun terikat (Frick, 1998). 
Tabel 1. Hubungan Masing-masing elemen dan Fungsinya

\begin{tabular}{|c|c|c|c|}
\hline No & Elemen-elemen pembentuk & Jenis Material & Fungsi \\
\hline 1 & Pondasi & Batu Kali & Sebagai landasan tanpa ada ikatan \\
\hline 2 & Tiang atau tameh & $\begin{array}{l}\text { Bak tu, Bak Mane, } \\
\text { Bak Panah }\end{array}$ & $\begin{array}{l}\text { Sebagai rangka utama, penahan balok } \\
\text { toi dan ro' dan dudukan bara panyang } \\
\text { dan bara linteung }\end{array}$ \\
\hline 3 & Toi & Bak tu, Bak Mane, & $\begin{array}{l}\text { Menghubungkan tiang-tiang \& } \\
\text { diperkuat dengan pasak, sebagai } \\
\text { penahan tiang (dalam arah melintang), } \\
\text { sebagai dudukan 'gratan' }\end{array}$ \\
\hline 4 & Ro' & Bak tu, Bak Mane, & $\begin{array}{l}\text { Menghubungkan tiang-tiang \& } \\
\text { diperkuat dengan pasak, sebagai } \\
\text { penahan tiang (dalam arah memanjang) }\end{array}$ \\
\hline 5 & Neuduk lhue/ Gratan & Bak Tu, Bak panah & Tempat dudukan lhue/balok lantai \\
\hline 6 & Peulangan & Bak panah & $\begin{array}{l}\text { Penahan balok toi, penutup ruang } \\
\text { rambat }\end{array}$ \\
\hline 7 & lhue & Bak Tu, Bak panah & $\begin{array}{l}\text { Berupa balok lantai, tempat dudukan } \\
\text { papan lantai }\end{array}$ \\
\hline 8 & Bara panyang & Bak Panah & $\begin{array}{l}\text { Menghubungkan tiang-tiang pada } \\
\text { bagian atas sekaligus menahan rangka } \\
\text { atap }\end{array}$ \\
\hline 9 & $\begin{array}{l}\text { Rangka atap: bara linteung, diri, gaseu } \\
\text { gantueng, indreng \& diri, beulabah. } \\
\text { Pembentuk bidang segitiga }\end{array}$ & Bak tu & $\begin{array}{l}\text { Sebagai penahan penutup atap } \\
\text { Bara linteung menghubungkan tiang } \\
\text { dalam arah melintang. } \\
\text { Diri menahan tuleng rueng. } \\
\text { Tuleng rueng menahan gaseu gantueng } \\
\text { Indreng sebagai penahan gaseu gantong }\end{array}$ \\
\hline
\end{tabular}

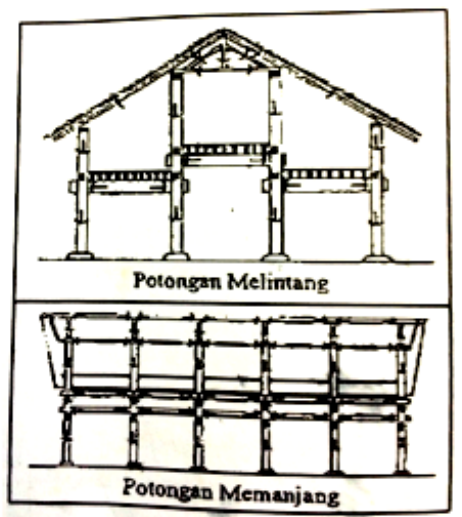

Gambar 6. Gaya-Gaya Batang Akibat Beban Bangunan

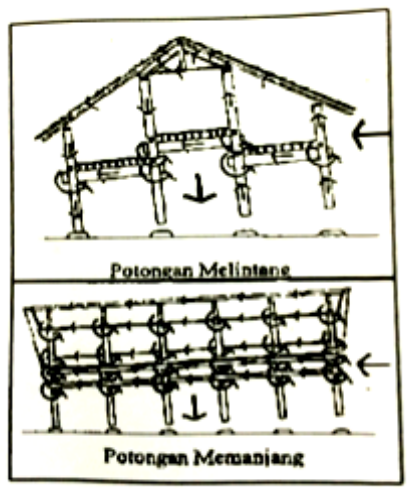

Gambar 7. Gaya-gaya Batang Akibat Beban Gempa
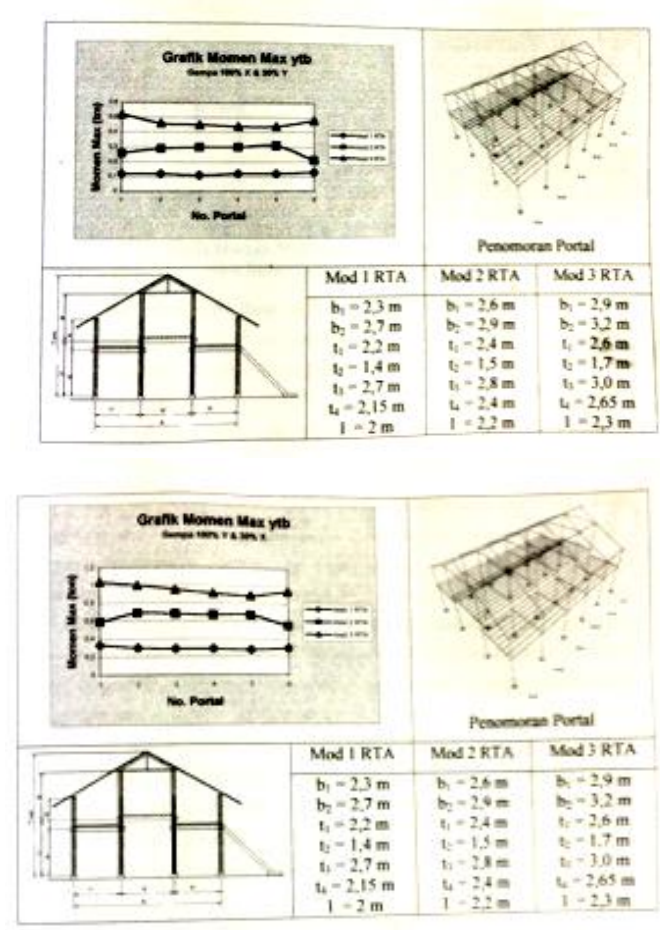

Gambar 8. Hasil Simulasi SAP 2000 
Tabel 2. Hasil Analisa Perhitungan Gaya batang dan Gaya Gempa

\begin{tabular}{|c|c|c|r|r|r|r|}
\hline \multirow{2}{*}{ No. Portal } & $\begin{array}{c}\text { Gaya Geser } \\
\text { max Kolom }\end{array}$ & $\begin{array}{c}\text { Momen } \\
\text { Balok }\end{array}$ & $\begin{array}{c}\text { Gaya Tekan } \\
\text { Balok }\end{array}$ & \multirow{2}{*}{$\begin{array}{c}\text { V Joint } \\
\text { Qa-C (kg) }\end{array}$} & $\begin{array}{c}\text { Teg. Geser } \\
\text { ytb }\end{array}$ & $\begin{array}{c}\text { Teg. Geser } \\
\text { izin }\end{array}$ \\
\cline { 2 - 4 } & Qa (kg) & (kgcm) & C (kg) & & (kg/cm2) & $\mathbf{1 8 ~} \mathbf{~ k g / c m 2 ~}$ \\
\hline & & & & & & \\
1 & 290 & 104000 & 7428,571429 & 7138,57143 & 10,1041351 & $\tau_{\text {ytb }}<\tau_{\text {izin }}$ \\
2 & 320 & 100000 & 7142,857143 & 6822,85714 & 9,65726418 & $\tau_{\text {ytb }}<\tau_{\text {izin }}$ \\
3 & 300 & 95000 & 6785,714286 & 6485,71429 & 9,18006268 & $\tau_{\text {ytb }}<\tau_{\text {izin }}$ \\
4 & 280 & 91000 & 6500 & 6220 & 8,8039632 & $\tau_{\text {ytb }}<\tau_{\text {izin }}$ \\
5 & 270 & 89000 & 6357,142857 & 6087,14286 & 8,61591346 & $\tau_{\text {ytb }}<\tau_{\text {izin }}$ \\
6 & 200 & 94000 & 6714,285714 & 6514,28571 & 9,22050349 & $\tau_{\text {ytb }}<\tau_{\text {izin }}$ \\
\hline
\end{tabular}

Hasil pengamatan pengujian maket model rumah Aceh terhadap gaya gempa, terlihat bahwa masing-masing sistem struktur dalam kondisi stabil. Dalam hal ini masing-masing sambungan yang membentuk struktur rumah Aceh terikat dengan baik. Hanya pada bagianbagian yang tidak terikat, seperti dudukan konstruksi atau umpak yang menyebabkan secara keseluruhan konstruksi bergeser atau berpindah dari posisi dudukan awal.

Hasil pengamatan di atas menunjukkan bahwa suatu konstruksi harus mempunyai ikatan yang baik pada setiap joint atau hubunganhubungan yang membentuk suatu sistem struktur. Gaya gempa dalam arah horizontal dapat menyebabkan bangunan tergelincir dari pondasi bangunan. Jika bangunan terikat dengan baik pada pondasinya, akan memberikan kemampuan pondasi menahan dirinya sendiri terhadap pergeseran bangunan dalam arah horizontal (horizontal sliding friction) dan gaya lateral tanah dasar.

Masing-masing bagian pembentuk struktur rumah Aceh mampu untuk mempertahankan posisi dan kedudukan dari masing-masing elemen tersebut pada saat menerima beban gempa. Oleh karena itu struktur rumah Aceh tetap kokoh meskipun terjadi gempa.

Tabel 3. Respon dari Elemen-elemen Pembentuk Rumah Aceh terhadap Gempa

\begin{tabular}{|c|c|c|c|}
\hline No & $\begin{array}{c}\text { Elemen-elemen } \\
\text { pembentuk }\end{array}$ & Fungsi & Respon terhadap gempa \\
\hline 1 & Pondasi & Sebagai landasan tanpa ada ikatan & $\begin{array}{l}\text { Tidak dapat menahan struktur pada posisinya } \\
\text { (terjadi pergeseran) baik dalam arah } \\
\text { memanjang maupun dalam arah melintang }\end{array}$ \\
\hline 2 & Tiang atau tameh & $\begin{array}{l}\text { Sebagai rangka utama } \\
\text { Menerima beban-beban dari elemen } \\
\text { lainnya dan menyalurkan ke dasar } \\
\text { pondasi }\end{array}$ & Menahan posisi toi dan ro' tetap pada keduduka \\
\hline 3 & Toi dan rok & $\begin{array}{l}\text { Toi Menghubungkan tiang-tiang } \\
\text { dalam arah melintang } \\
\text { Ro' menghubungkan tiang-tiang } \\
\text { dalam arah memanjang } \\
\text { Hubungan antara toi-tiang dan ro'- } \\
\text { tiang diperkuat dengan pasak }\end{array}$ & $\begin{array}{l}\text { Toi Menahan posisi tameh tetap pada } \\
\text { dudukannya dalam arah melintang } \\
\text { Ro' menahan posisi tameh tetap pada } \\
\text { dudukannya dalam arah memanjang }\end{array}$ \\
\hline 4 & Peulangan & $\begin{array}{l}\text { merupakan balok yang } \\
\text { menghubungkan tameh bagian tengah } \\
\text { dalam arah memanjang }\end{array}$ & $\begin{array}{l}\text { Menahan posisi tameh dan toi tetap pada } \\
\text { posisinya. }\end{array}$ \\
\hline 5 & Bara panyang & $\begin{array}{l}\text { Menghubungkan tiang-tiang dalam } \\
\text { arah memanjang pada bagian atas } \\
\text { sekaligus menahan rangka atap }\end{array}$ & $\begin{array}{l}\text { Menahan posisi tameh tetap pada } \\
\text { dudukannya pada bagian atas }\end{array}$ \\
\hline
\end{tabular}


Tabel 3. (Lanjutan)

\begin{tabular}{|c|c|c|c|}
\hline No & $\begin{array}{l}\text { Elemen-elemen } \\
\text { pembentuk }\end{array}$ & Fungsi & Respon terhadap gempa \\
\hline 6 & $\begin{array}{l}\text { Rangka atap: bara } \\
\text { linteung, diri, gaseu } \\
\text { gantueng, indreng \& } \\
\text { diri }\end{array}$ & $\begin{array}{l}\text { Rangka atap sebagai penahan penutup } \\
\text { atap } \\
\text { Bara linteung adalah balok yang } \\
\text { menghubungkan tiang dalam arah } \\
\text { melintang, merupakan balok tarik } \\
\text { pada rangka atap } \\
\text { Diri merupakan balok tekan pada } \\
\text { rangka atap } \\
\text { Gaseu gantoeng merupakan batang } \\
\text { tarik. } \\
\text { Tuleng rueng merupakan puncak dari } \\
\text { konstruksi atap, menghubungkan } \\
\text { antara satu rangka atap dengan yang } \\
\text { lainnya } \\
\text { Indreng sebagai penahan gaseu } \\
\text { gantong }\end{array}$ & $\begin{array}{l}\text { Bara Linteung Menahan posisi tiang/tameh } \\
\text { tetap pada dudukan dalam melintang } \\
\text { Mendukung posisi masing-masing elemen } \\
\text { pembentuk rangka atap sebagai satu kesatuan } \\
\text { yang utuh. }\end{array}$ \\
\hline
\end{tabular}

Material yang digunakan pada rumah Aceh adalah kayu yang merupakan salah satu material yang ringan. Jenis material dengan karakteristik ringan merupakan salah satu syarat terhadap bahan bangunan yang digunakan di daerah gempa.

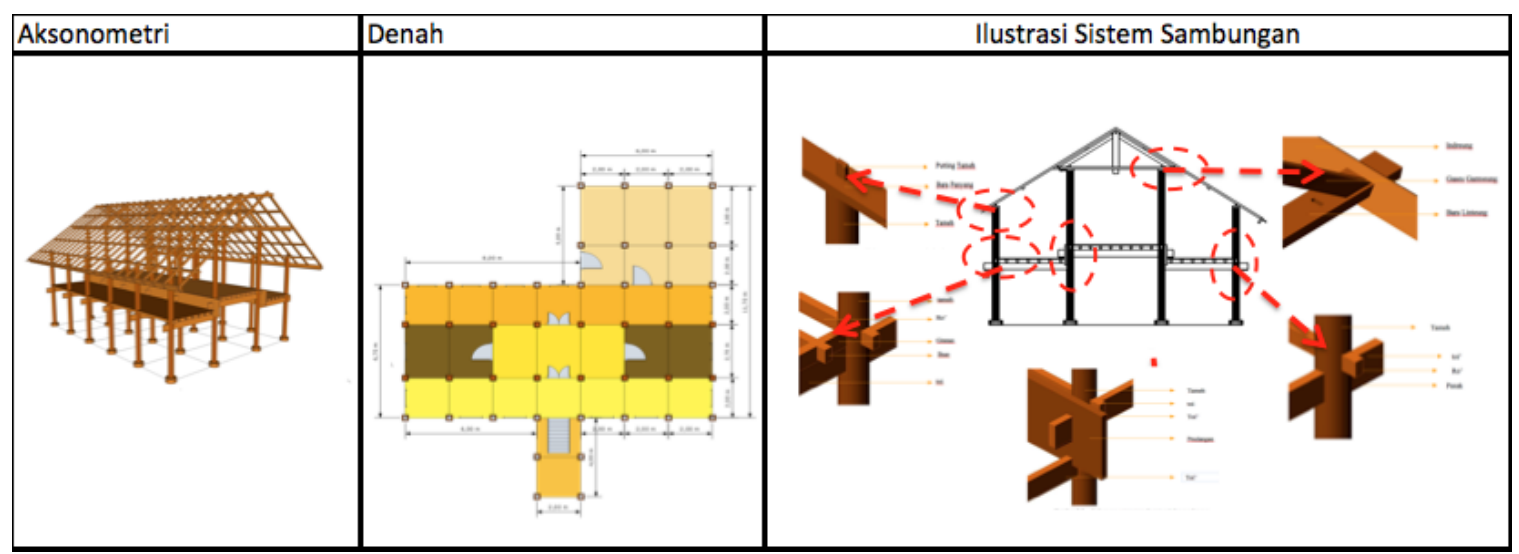

Gambar 9. Pemetaan Sistem Sambungan Rumah Tradisional Aceh dalam Merespon Gempa

Material konstruksi terdiri dari bahan kayu yang merupakan material yang ringan dan mempunyai karakteristik dapat menahan gayagaya yang berusaha untuk menarik, menggeser, memuntir, membelah dan melengkungkan kayu.

Masing-masing elemen pembentuk rumah Aceh saling mempertahankan diri dalam merespon gempa. Perilaku elemen dalam merespon gempa arah memanjang dan melintang ditentukan oleh hubungan yang terbentuk pada sambungan antara balok toi, ro',pasak, peulangan dan tiang, yang merupakan bagian badan. Pada rangka atap kemampuan konstruksi merespon gempa dalam arah memanjang dan melintang terbentuk dari hubungan antara tiang, bara panyang, bara linteung, diri, geseu gantoeng dan indreung, yang merupakan bagian kepala.

\section{KESIMPULAN}

Rumah Aceh tidak menggunakan pondasi, hanya ada umpak atau batu yang datar sebagai landasan tiang-tiang. Kondisi ini menyebabkan pergeseran struktur secara keseluruhan, dimana posisi tiang-tiang berpindah dari landasannya, tetapi tidak menyebabkan rumah Aceh roboh. 
Tiang atau Tameh merupakan rangka utama konstruksi rumah Aceh, bertugas menahan posisi toi dan ro' dalam merespon gempa dalam arah memanjang dan melintang tetap pada kedudukannya.

Toi merupakan balok yang menghubungkan tiang-tiang dalam arah melintang bertugas menahan posisi tiang dalam merespon gempa dalam arah melintang. Ro' merupakan balok yang menghubungkan tiang dalam arah memanjang, bertugas menahan posisi tiang dalam merespon gempa dalam arah memanjang. Hubungan antara toi-tiang dan ro'tiang diperkuat oleh pasak. Peulangan merupakan balok yang menghubungkan tiangtiang bagian tengah dalam arah memanjang, bertugas menahan toi untuk merespon gempa dalam arah melintang dan menahan tiang untuk merespon gempa dalam arah memanjang dan melintang.

Bara Panyang merupakan balok yang menghubungkan tiang-tiang dalam arah memanjang yang dihubungkan oleh putting tameh. Bara panyang bertugas untuk menahan posisi tiang dalam merespon gempa dalam arah memanjang.

Rangka Atap terdiri dari Bara Linteung, Gaseu Gantoeng, Idreng dan Diri. Bara Linteung merupakan balok yang menghubungkan tiang-tiang bagian tengah dalam arah melintang. Erfungsi sebagai balok tarik dan menahan posisi tiang bagian dalam merespon gempa dalam arah melintang.

Joint-joint pada rumah Aceh diperkuat oleh pasak sebagai penahan elemen-elemen yang saling berhubungan dalam merespon gempa dalam arah memanjang maupun melintang.

Rumah Aceh merupakan rumah yang tahan terhadap gempa, secara keseluruhan masing-masing elemen struktural pembentuk rumah Aceh mampu dalam merespon gempa dalam arah memanjang dan melintang yang ditentukan oleh hubungan yang membentuk konstruksi rumah Aceh pada bagian kaki, badan dan kepala.

\section{Daftar Pustaka}

Boen, T. (1969) Dasar-Dasar Perencanaan Bangunan Tahan Gempa, Departemen Pekerjaan Umum, Bandung.
Departemen Pekerjaan Umum (1987) Pedoman Perencanaan Ketahanan Gempa untuk Rumah dan Gedung, Jakarta.

Frick, Heinz dan Purwanto, LMF. (1998) Sistem Bentuk Struktur Bangunan: DasarDasar Konstruksi dalam Arsitektur, Kanisius, Semarang.

Green, Norman B. (1981) Earthquake Resistant: Building Design and Construction, Van Nostrand Reinholld Company, New York.

Hurgronje, Snouck (1985) Aceh Dimata Kolonialis, Yayasan Soko Guru, Jakarta

Kusuma, Gideon dan Andriono, Takim (1993) Desain Struktur Rangka Beton Bertulang di Daerah Rawan Gempa, Berdasarkan SKSNI T-15-1991-03, Erlangga, Jakarta.

Leigh, Barbara (1989) Tangan-tangan Trampil, Djambatan, Jakarta.

Lippsmeier, Georg (1994) Bangunan Tropis (Tropenbau Building in the Tropics). Erlangga, Jakarta.

Meutia, Erna (2003) Kajian Pengaru Gempa Terhadap Sistem Struktur Tradisional Aceh, Program Magister Arsitektur Program Pasca Sarjana Institut Bandung.

Meutia, Erna dkk (2008) Kajian Elemen-Elemen Pembentuk Struktur Rumah Tradisional Aceh dalam Merespon Gempa, Lembaga Penelitian, Banda Aceh.

Siddiq, Suwandojo (1999) Beberapa Tinjauan Aspek Bahan, Konstruksi dan Struktur Bangunan Tradisional Indonesia, Lokakarya Upaya Pelestarian Arsitektur Tradisional Indonesia Melalui Sistem Informasi, Jakarta. 